\title{
Purification and partial characterization of LdtP, a cell envelope modifying enzyme in Liberibacter asiaticus
}

\author{
Janelle F. Coyle, Fernando A. Pagliai, Dan Zhang, Graciela L. Lorca and Claudio F. Gonzalez* (D)
}

\begin{abstract}
Background: The aggressive spread of Liberibacter asiaticus, a bacterium closely associated with citrus greening, has given rise to an acute crisis in the citrus industry, making it imperative to expand the scientific knowledge base regarding L. asiaticus. Despite several endeavors to culture L. asiaticus, this bacterium has yet to be maintained in axenic culture, rendering identification and analysis of potential treatment targets challenging. Accordingly, a thorough understanding of biological mechanisms involved in the citrus host-microbe relationship is critical as a means of directing the search for future treatment targets. In this study, we evaluate the biochemical characteristics of CLIBASIA_01175, renamed LdtP (L,D-transpeptidase). Surrogate strains were used to evaluate its potential biological significance in gram-negative bacteria. A strain of $E$. coli carrying quintuple knock-outs of all genes encoding L,D-transpeptidases was utilized to demonstrate the activity of L. asiaticus LdtP.

Results: This complementation study demonstrated the periplasmic localization of mature LdtP and provided evidence for the biological role of LdtP in peptidoglycan modification. Further investigation highlighted the role of LdtP as a periplasmic esterase involved in modification of the lipid A moiety of the lipopolysaccharide. This work described, for the first time, an enzyme of the L,D-transpeptidase family with moonlighting enzyme activity directed to the modification of the bacterial cell wall and LPS.
\end{abstract}

Conclusions: Taken together, the data indicates that LdtP is a novel protein involved in an alternative pathway for modification of the bacterial cell, potentially affording L. asiaticus a means to survive within the host.

Keywords: Citrus greening, LdtP, Liberibacter asiaticus, L,D-transpeptidase, Esterase, Lipopolysaccharide, Peptidoglycan, Cell envelope

\section{Background}

Citrus greening, or huanglongbing (HLB), is the most formidable and devastating disease to ever affect the citrus industry. Citrus is an essential crop grown in areas $\pm 40^{\circ}$ latitude of the equator, with Brazil, China, and the United States as the top citrus producers worldwide [1,2]. The aggressive spread of HLB has given rise to an acute crisis for citrus growers with no proximately discernible curative control method.

HLB is associated with three species of fastidious, phloem-limited $\alpha$-proteobacteria: Liberibacter asiaticus in Asia and North America, Liberibacter africanus in

\footnotetext{
* Correspondence: cfgonzalez@ufl.edu

Department of Microbiology and Cell Science, Genetics Institute and Institute of Food and Agricultural Sciences, University of Florida, Gainesville, FL, USA
}

Africa, and Liberibacter americanus in Brazil [1]. L. asiaticus is the most pathogenic of these species and is closely associated with HLB in the United States $[1,2]$. It is transmitted among citrus plants via the feeding activities of the psyllid vector, Diaphorina citri $[1,2]$. Following infiltration and colonization of the citrus host, the HLB pathogen spreads rapidly to all plant tissues causing yellow shoots, non-symmetrical blotchy mottled leaves, and small, deformed, abnormally colored fruit [2]. Although several treatment methods have been investigated, current HLB management is limited to the control of the psyllid vector and the removal of infected trees $[1,2]$. It has been estimated that without intervention, the citrus industry will diminish substantially within $2-10$ years in affected regions. As such, it is

(C) The Author(s). 2018 Open Access This article is distributed under the terms of the Creative Commons Attribution 4.0 International License (http://creativecommons.org/licenses/by/4.0/), which permits unrestricted use, distribution, and 
imperative to develop new antimicrobial therapies against HLB for the preservation of this industry.

Despite several endeavors to culture $L$. asiaticus, this bacterium has yet to be maintained in axenic culture, rendering identification and analysis of potential treatment targets challenging. Additionally, genes encoding toxins or other pathogenicity genes were not identified by an analysis of the $L$. asiaticus genome [3]. However, a genome analysis was successful in detecting only 10 transcription factors in the genome, suggesting that targeted chemical treatment directed at one individual transcription factor may result in pleiotropic effects, thereby reducing viability of the pathogen [4].

LdtR, a member of the multidrug resistance regulator (MarR) family of transcriptional regulators, was functionally characterized as a target for the development of novel $L$. asiaticus treatments [5]. In the $L$. asiaticus genome, the $l d t R$ gene is encoded immediately upstream from the $l d t P$ gene, which encodes a putative L,D-transpeptidase (LD-TPase). This gene arrangement is highly conserved among all members of the Rhizobiaceae family. LdtR acts as a transcriptional activator of both $l d t R$ and $l d t P$ by binding to the promoter regions of these genes [5]. In a closely-related species, Sinorhizobium meliloti, bacteria harboring a disruption in $l d t R$ or $l d t P$ exhibited reduced tolerance to osmotic stress, as well as a short-cell phenotype attributed to alterations in cell wall architecture. Further, it was established that the activation of transcription of $l d t P$ by LdtR is essential for the osmotic stress response, and, specifically, it is predicted that LdtP-mediated remodeling of the bacterial cell wall is vital for adaptation and resistance to osmotic stress. Since the L,D-transpeptidase enzymes are involved in bacterial cell wall crosslinking, allowing an increased resistance to osmotic stress, we decided to analyze the characteristics of the encoded protein.

LD-TPases are enzymes involved in the biosynthesis and rearrangement of the bacterial cell wall, a durable and flexible peptidoglycan polymer responsible for maintaining cell shape and protecting the cell from environmental stressors [6]. Peptidoglycan is a versatile structure composed of linear glycan chains linked together by peptide cross-bridges, creating a lattice-like mesh [7]. The subunit of peptidoglycan, synthesized in the cytoplasm, is a disaccharide-peptide composed of an $\mathrm{N}$-acetylmuramic acid-N-acetylglucosamine (MurNAc-GlcNAc) dimer linked via a $\beta-1,4-$ glycosidic bond with a linear pentapeptide stem. This stem consists of $\mathrm{L}-\mathrm{Ala}^{1}-\mathrm{D}-\mathrm{Glu}^{2}$-meso$\mathrm{DAP}^{3}-\mathrm{D}-\mathrm{Ala}^{4}-\mathrm{D}-\mathrm{Ala}^{5}$ linked to the MurNAc moiety in most gram-negative bacteria (Fig. 1a). This precursor is flipped across the inner membrane into the periplasm, where glycosyltransferases catalyze bond formation between GlcNAc of the precursor subunit and MurNAc of the growing glycan chain. LD-TPases and
D,D-transpeptidases (DD-TPases) are responsible for cross-link formation between peptide stems on adjacent glycan chains, producing a rigid, three-dimensional peptidoglycan sacculus.

The degree and type of peptidoglycan cross-linking varies among bacterial species and even within a species, depending on the growth phase and environmental conditions. The main type of linkage is the 4-3 type generated by DD-TPases, whereas LD-TPases catalyze the formation of the less abundant 3-3 linkages (Fig. 1b). DD-TPases, also known as penicillin-binding proteins, are sensitive to all classes of $\beta$-lactam antibiotics and contain an active-site serine residue that facilitates the formation of 4-3 cross-links. These enzymes cleave the terminal D-Ala ${ }^{5}$ from a pentapeptide donor stem adjoining the carbonyl of the resulting D-Ala ${ }^{4}$ to the amine group of mesoDAP ${ }^{3}$ on an acceptor stem. Alternatively, LD-TPases are insensitive to all classes of $\beta$-lactam antibiotics except the carbapenems, contain an active-site cysteine residue, and require the activity of D,D-carboxypeptidases to generate a tetrapeptide donor stem. LD-TPases generate 3-3 cross-links by cleaving the D- $\mathrm{Ala}^{4}$ of a tetrapeptide donor stem and linking mesoDAP ${ }^{3}$ on the donor stem to the mesoDAP ${ }^{3}$ of the acceptor stem. An increase in the cross-linking activity of LD-TPases induces increased $\beta$-lactam resistance, confers protection during the stationary phase of growth, and fortifies the cell wall upon exposure to stressors such as temperature fluctuation, osmotic stress, and nutrient limitation.

The goal of this study was to thoroughly characterize LdtP with bioinformatic techniques and to utilize a genetic approach to observe the phenotypic influence of LdtP overexpression in a strain of Escherichia coli lacking all five of the encoded LD-TPases [7]. The E. coli quintuple mutant ( $\Delta \mathrm{ldt} 5)$ and Liberibacter crescens were used as models in this study because $L$. asiaticus cannot be cultured in the laboratory.

\section{Results}

\section{Characterization of LdtP}

Analysis of the L. asiaticus str. Psy62 genome revealed a single putative LD-TPase, encoded by CLIBASIA_01175, renamed $l d t P$. This gene encodes a hypothetical protein (Accession: ACT56823) composed of 431 amino acids assigned to COG2989 (murein L,D-transpeptidase YcbB/ YkuD) with two identified conserved domains: (1) a peptidoglycan-binding domain (pfam01471); and (2) two YkuD L,D-transpeptidase catalytic domains (pfam03734) (Fig. 2a) [8]. Members of the YkuD superfamily are typified by a completely conserved active-site cysteine and histidine residue, as well as a third residue that accepts a hydrogen bond from histidine. According to a PSI-Blast multiple sequence alignment (Fig. $2 \mathrm{~b}$ ), this catalytic triad is composed of Cys343, His324, and Asp325. 


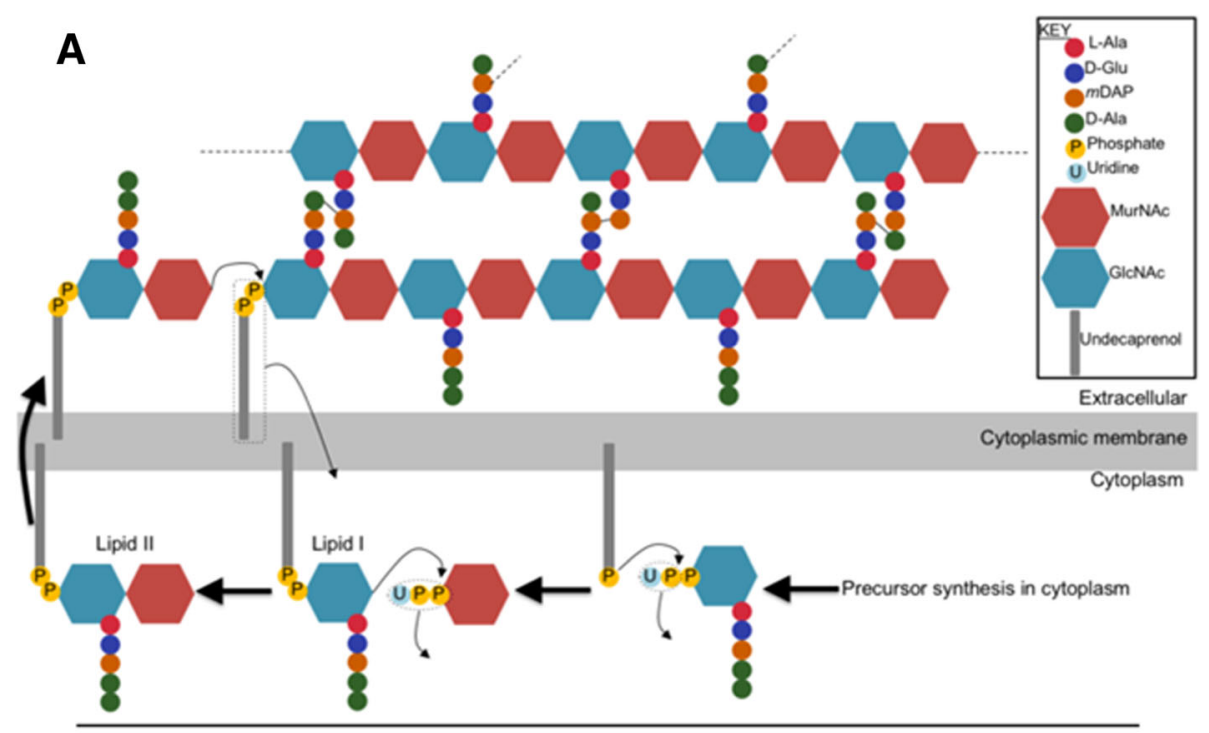

B
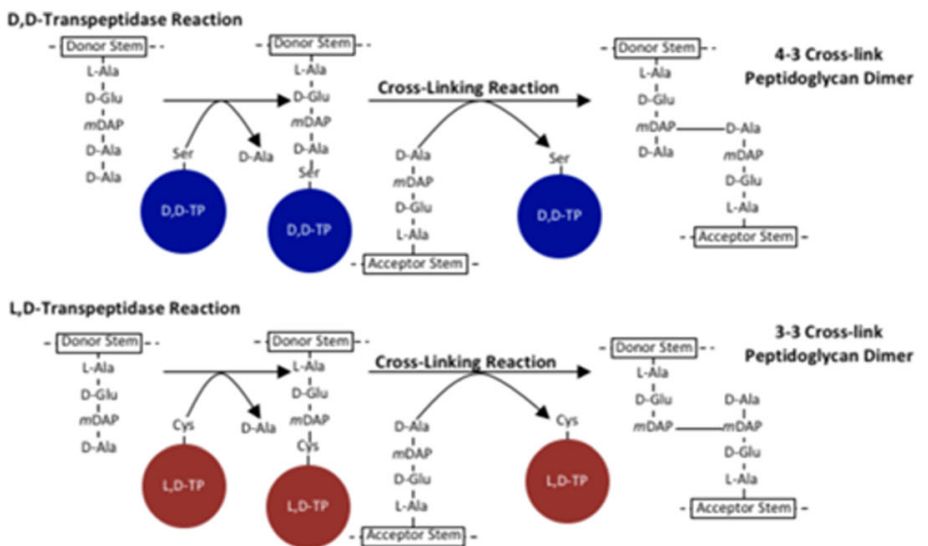

Fig. 1 Biosynthesis of the bacterial cell wall. a Diagram of the synthesis of the cell wall in a gram-negative bacterium. $\mathbf{b}$ Mechanism of the crosslinking reaction catalyzed by D,D-TPases and L,D-TPases

The $l d t P$ sequence was predicted by the Phobius server to encode an N-terminal signal peptide that directs LdtP to the cytoplasmic membrane for export into the periplasm. There, the mature protein has access to the cell wall and can participate in biosynthesis and rearrangement activities. The signal peptide is cleaved between Ser25 and Lys 26 as LdtP is transported into the periplasm [9]. Following cleavage of the signal peptide, LdtP was calculated to have a theoretical molecular mass of $46.5 \mathrm{kDa}$ and a pI of 5.82 [10]. This molecular mass was confirmed following purification of recombinant His-tagged LdtP through SDS-PAGE (Additional file 1: Figure S1).

The three-dimensional structure of LdtP was modeled by the Phyre2 server (Fig. 2c). The template for the construction of this model was an LD-TPase from Mycobacterium tuberculosis, $\mathrm{Ldt}_{\mathrm{Mt} 1}$ (PDB: 4JMX) with 99.5\% confidence over the modeled residues, Pro98-Leu356
[11]. The structural alignment data was in agreement with the sequence alignment data with regard to the predicted catalytic triad [11].

\section{LdtP is a periplasmic protein}

The predicted signal peptide of LdtP indicates transport of this protein into the periplasm. In order to determine the subcellular localization of LdtP, the entire $1296 \mathrm{bp}$ sequence of $l d t P$ was cloned into pBAD24, and the DNA sequence for a C-terminal FLAG-tag was inserted to allow for visualization via western blot. E. coli BW25113 (WT),

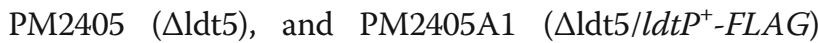
were grown in the absence or presence of $0.02 \%(w / v)$ arabinose for induction of $l d t P$ expression, and cultures were grown to $\mathrm{OD}_{600}=1.0$. Cells were fractionated into cytoplasmic, periplasmic, and membrane fractions and analyzed by western blot using an anti-FLAG antibody for 


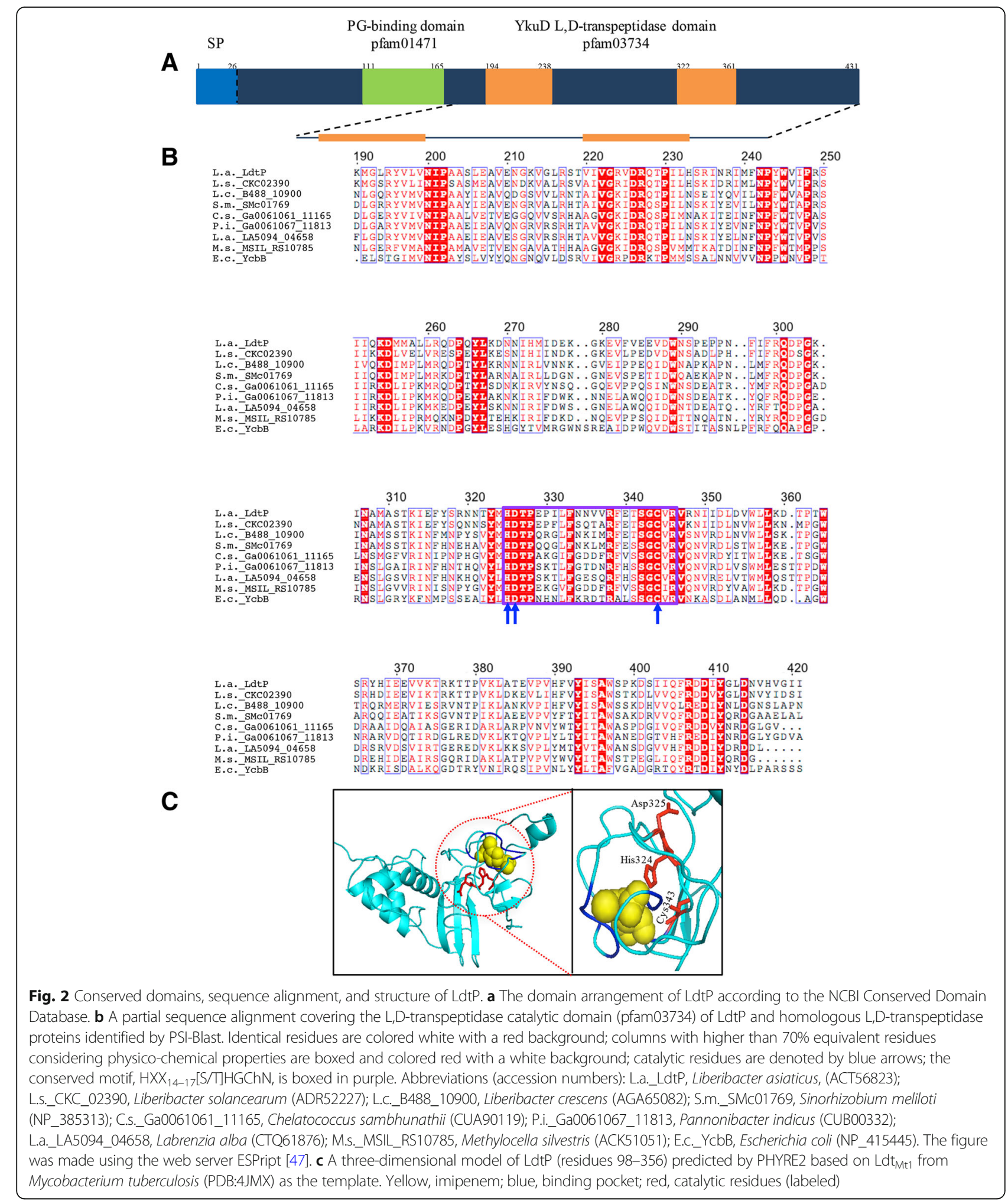

detection. A single band was observed in the periplasmic fraction of PM2405A1 with a molecular weight of $\sim 46$ $\mathrm{kDa}$, corresponding precisely with the theoretical molecular weight of LdtP (Fig. 3). No other bands were detected. These results clearly indicate that LdtP is transported to the periplasm for activity. 


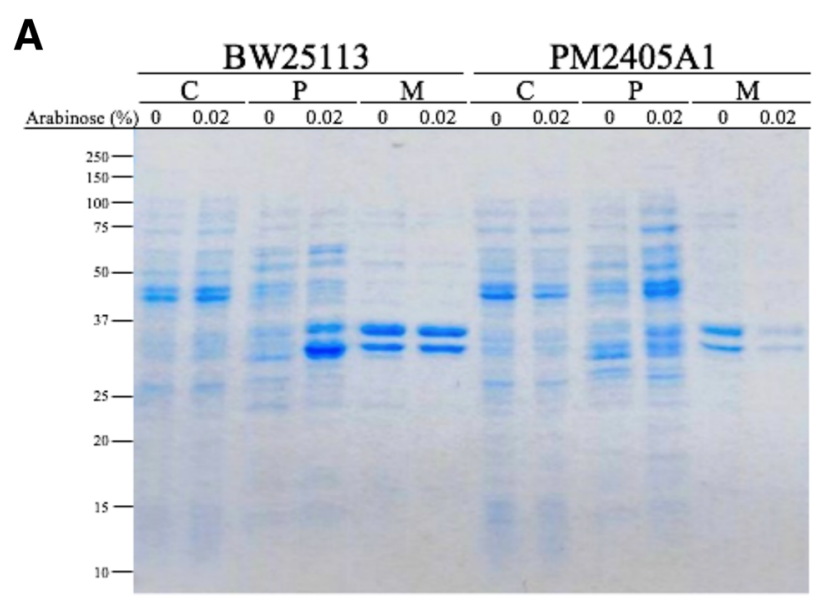

$\mathbf{B}$

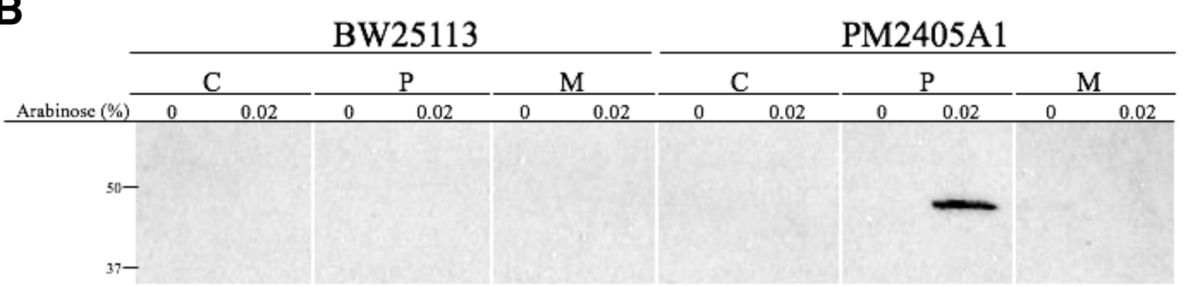

Fig. 3 Cellular localization of LdtP. E. coli BW25113 and E. coli PM2405A1 grown in the absence and presence of 0.02\% arabinose were separated into cell fractions (Panel a), as described, and analyzed by western blot (Panel b). Cytoplasmic (C), periplasmic (P), and membrane (M) fractions were probed with anti-FLAG antibody to identify the LdtP-FLAG protein

\section{Idt $P_{L c}$ expression is induced under osmotic stress}

\section{conditions in L. crescens}

The expression of LdtP was previously shown to be modulated by the LdtR transcriptional regulator, a transcription factor known to regulate the expression of numerous proteins involved in the osmotic stress response [5]. LdtP was also specifically implicated as a protein critical for cell viability upon exposure to conditions with high osmolarity, such as those encountered in the phloem of the citrus tree. In order to explore this hypothesis, the level of expression of $l d t P_{L c}\left(B 488_{-} 10900\right)$ was analyzed via qRT-PCR following incubation of Liberibacter crescens in BM7 culture media amended with non-lethal concentrations of $\mathrm{NaCl}(50 \mathrm{mM}, 100 \mathrm{mM})$ or sucrose $(75 \mathrm{mM}, 100$ $\mathrm{mM}, 150 \mathrm{mM}$ ). L. crescens is a phylogenetically close relative to $L$. asiaticus that is used as a surrogate strain due to the inability to maintain cultures of $L$. asiaticus under laboratory conditions. As expected, under our laboratory conditions, the rate of expression of LdtP increased in the presence of the high osmolarity culture media, up to 2.33 \pm 0.36 fold in the presence of $100 \mathrm{mM} \mathrm{NaCl}$ and $2.45 \pm$ 0.22 fold in the presence of $150 \mathrm{mM}$ sucrose (Fig. 4). This increase in expression of LdtP correlates with the previously published results and further supports a critical role for LdtP in osmotic stress tolerance by $L$. crescens, as well as L. asiaticus [5].

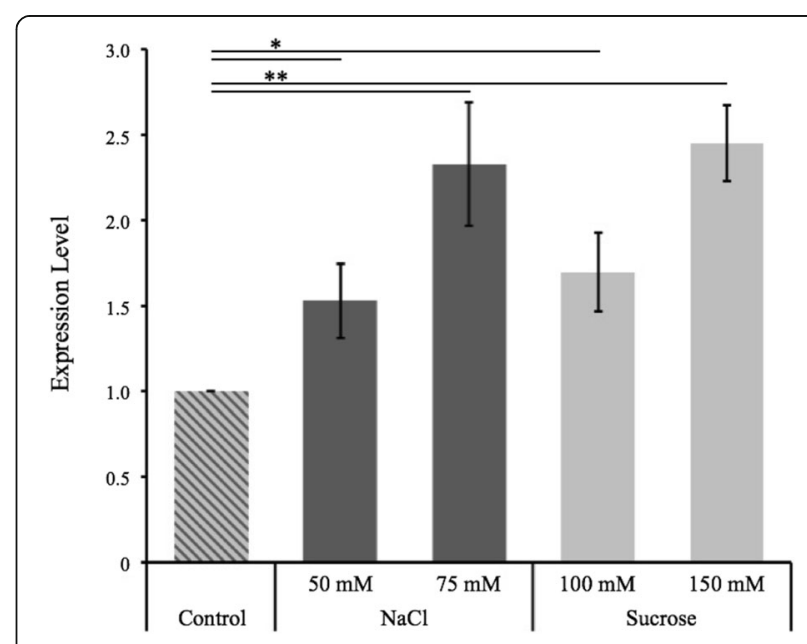

Fig. 4 Level of expression of $I d t P_{L C}$ under osmotic stress conditions. The expression level of $I d t P_{L C}$ (B488_10900) was calculated against a control containing no added $\mathrm{NaCl}$ or sucrose and normalized with an internal standard, $16 \mathrm{~S}$ rRNA. Values are given as the mean fold induction compared to the control with three biological replicates per condition. Statistical significance was determined using a Student's t-test $\left({ }^{*} p<0.05,{ }^{* *} p<0.01\right)$ 
Complementation of E. coli PM2405 with LdtP results in a slow-growth phenotype

The ability of LdtP to complement a strain of $E$. coli lacking all five of the encoded LD-TPases, PM2405 $(\Delta \mathrm{ldt} 5)$, was investigated. The full sequence for $l d t P$ was cloned into the arabinose-inducible plasmid pBAD24 generating pJFC1 [12]. PM2405A $\left(\Delta \mathrm{ldt} 5 / l d t P^{+}\right)$was produced by transforming PM2405 ( $\Delta \mathrm{ldt} 5)$ with pJFC1. Growth of E. coli BW25113 (WT), PM2405 ( $\Delta \mathrm{ldt} 5$ ), and PM2405A ( $\left.\Delta \mathrm{ldt} 5 / l d t P^{+}\right)$in liquid culture was monitored under two different conditions. The assay was directed to assess the effect of LdtP overexpression on the growth kinetics of these strains. The two conditions used were (1) various arabinose concentrations beginning at $T=0 \mathrm{~h}$ and (2) cultures induced after $3 \mathrm{~h}$ of growth with $0,0.02 \%$, or $0.2 \%$ arabinose.

In the first experiment, LB broth was supplemented with increasing concentrations of arabinose (0-0.02\%) before inoculation with each strain. This ensured immediate, constant induction of LdtP expression upon inoculation. The generation times for each strain at all concentrations of arabinose were calculated from the growth curve (Table 1, Additional file 2: Figure S2). When grown in the absence of arabinose, all three strains had similar duplication times $(1.36,1.44,1.51 \mathrm{~h}$, respectively). Over increasing concentrations of arabinose, the duplication times for BW25113 and PM2405 increased slightly, but none of these were statistically significant. When grown in the presence of 0.02 and $0.2 \%$ arabinose, the generation time for PM2405A increased by 148 and 126\%, respectively, when compared to BW25113 at the same concentration of arabinose. These results are statistically significant in a Student's t-test $(p<0.001)$ and indicate that the expression of LdtP in the quintuple knock-out strain causes a dramatic alteration in cell physiology and as a result, growth phenotype.

In the second experiment, strains were grown in terrific broth in the absence of arabinose for $3 \mathrm{~h}$, at which time $0,0.02 \%$, or $0.2 \%(w / v)$ arabinose was added to the indicated cultures. Following induction with arabinose at either concentration, BW25113 and PM2405 showed the same growth $\left(\mathrm{OD}_{600}\right)$ as the strains that were not induced; however, the growth of PM2405A was arrested almost immediately upon induction (Fig. 5). It can be deduced from this rapid alteration in growth phenotype that expression of LdtP results in an abrupt change in cell physiology that is so drastic as to almost completely cease cellular growth.

\section{Expression of LdtP results in changes in peptidoglycan cross-linking}

Peptidoglycan from E. coli BW25113 and PM2405A1 strains grown with and without arabinose was isolated, digested into muropeptides, and separated by reversephase high-performance liquid chromatography (HPLC). Each peak on the HPLC chromatogram (Fig. 6) corresponds to a different muropeptide. Peaks are numbered in accordance with Additional file 3: Table S1. Comparison of BW25113 and PM2405 revealed that 15 out of the 39 muropeptides disappeared with deletion of the five LD-TPases in BW25113. Disappearance of muropeptides containing a 3-3 cross-link and muropeptides linked to Braun's lipoprotein is expected, since PM2405 does not produce the enzymes responsible for forming these cross-links [13]. Expression of LdtP in the quintuple knock-out strain, PM2405A, restored production of 5 missing muropeptides. Although the specific muropeptides affected were not identified, the reappearance of missing muropeptides clearly indicates that LdtP is involved in rearrangement of the bacterial cell wall.

\section{LdtP displays esterase activity in solution}

A PSI-Blast multiple sequence alignment completed during the in silico analysis above, identified several amidases from different species as having high degrees of conservation to the linear protein sequence of LdtP. In vitro assays to evaluate amidase and esterase activities were performed with purified $\mathrm{His}_{6 \mathrm{X}}$-LdtP and model substrates, including amides, carboxyl esters ( $p$-nitrophenyl esters), thioesters (acyl-CoA substrates), and aryl esters (naphthyl esters) of various chain lengths. Although LdtP showed weak or no activity toward the

Table 1 Generation time of strains induced with increasing concentrations of arabinose

\begin{tabular}{|c|c|c|c|c|c|c|}
\hline & \multicolumn{2}{|l|}{ BW25113 } & \multicolumn{2}{|l|}{ PM2405 } & \multicolumn{2}{|l|}{ PM2405A } \\
\hline & $\begin{array}{l}\text { Growth rate constant, } \\
\text { k (generations/h) }\end{array}$ & $\begin{array}{l}\text { Mean } \\
\text { generation time (h) }\end{array}$ & $\begin{array}{l}\text { Growth rate constant, } \\
\text { k (generations } / \mathrm{h} \text { ) }\end{array}$ & $\begin{array}{l}\text { Mean generation } \\
\text { time }(\mathrm{h})\end{array}$ & $\begin{array}{l}\text { Growth rate constant, } \\
\text { k (generations } / \mathrm{h} \text { ) }\end{array}$ & $\begin{array}{l}\text { Mean generation } \\
\text { time }(h)\end{array}$ \\
\hline $0 \%$ Ara & $0.74 \pm 0.016$ & $1.36 \pm 0.03$ & $0.70 \pm 0.002$ & $1.44 \pm 0.01$ & $0.66 \pm 0.013$ & $1.51 \pm 0.03$ \\
\hline 0.0002\% Ara & $0.68 \pm 0.007$ & $1.47 \pm 0.02$ & $0.67 \pm 0.010$ & $1.50 \pm 0.03$ & $0.51 \pm 0.013$ & $1.96 \pm 0.05$ \\
\hline $0.002 \%$ Ara & $0.70 \pm 0.006$ & $1.43 \pm 0.01$ & $0.67 \pm 0.010$ & $1.50 \pm 0.03$ & $0.47 \pm 0.027$ & $2.11 \pm 0.12$ \\
\hline $0.02 \%$ Ara & $0.67 \pm 0.012$ & $1.49 \pm 0.03$ & $0.64 \pm 0.009$ & $1.56 \pm 0.02$ & $0.27 \pm 0.002$ & $3.69 \pm 0.03^{* *}$ \\
\hline $0.2 \%$ Ara & $0.65 \pm 0.016$ & $1.54 \pm 0.04$ & $0.63 \pm 0.058$ & $1.59 \pm 0.15$ & $0.29 \pm 0.005$ & $3.48 \pm 0.07^{* *}$ \\
\hline
\end{tabular}

Generation times were calculated from the growth curves in Additional file 2: Figure S2. Values are given as mean \pm SD ( $n=3$ ). Data were analyzed using Student's t-test. **P-values $\leq 0.001$ comparing mean generation time of PM2405 or PM2405A with mean generation time of BW25113 was considered statistically significant 


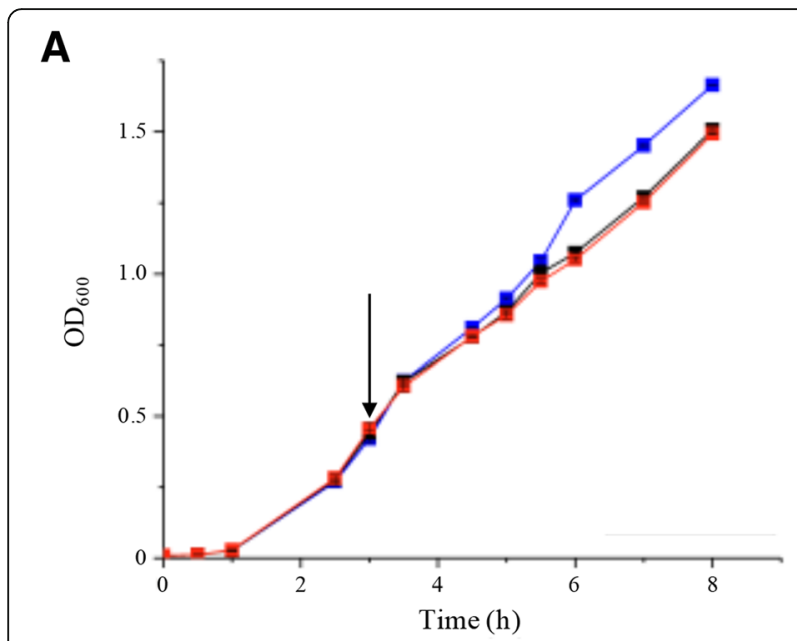

B

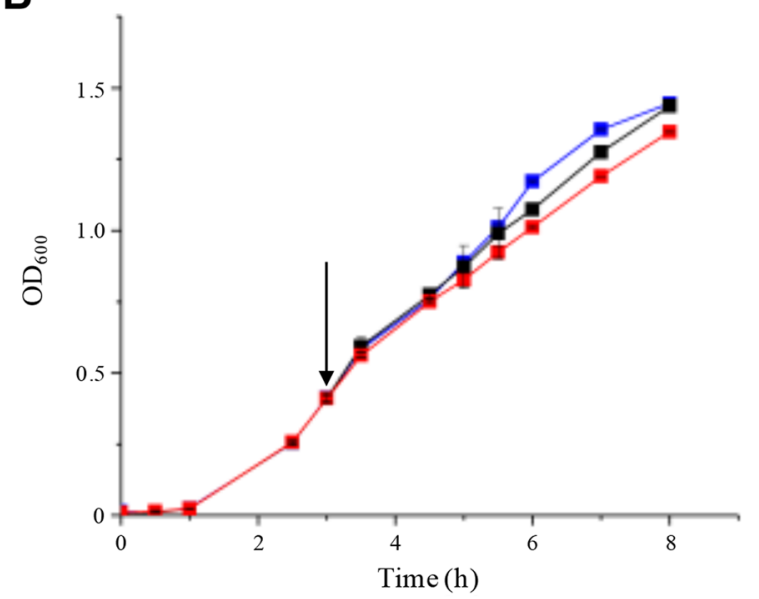

C

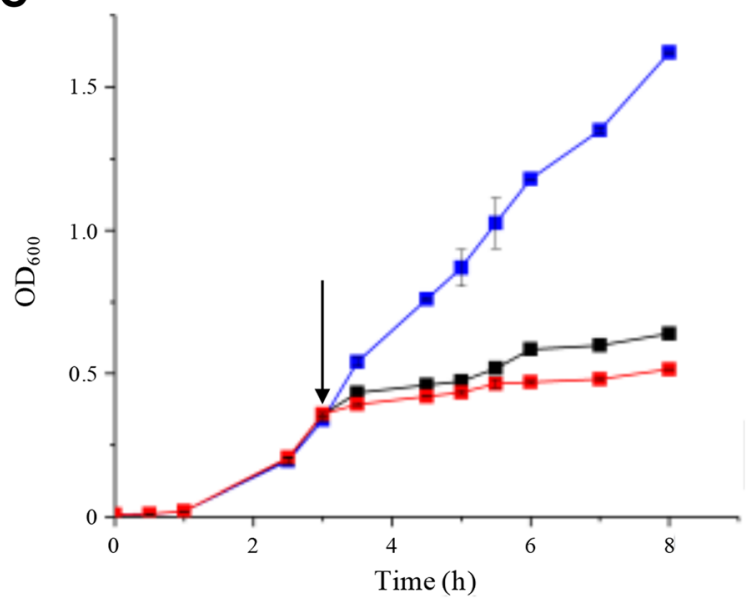

Fig. 5 Standard growth curve upon induction of IdtP expression. $E$. coli BW25113 (a), PM2405 (b), and PM2405A (c) cultures were grown at $37^{\circ} \mathrm{C}$ in Terrific broth. Cultures were induced at $3 \mathrm{~h}$ of growth with $0 \%$ (blue), $0.02 \%$ (black), or $0.2 \%$ (red) arabinose. Growth was monitored at $\mathrm{OD}_{600}$ at the indicated time points. Arrow indicates time of induction. Plotted values represent the mean \pm standard deviation of three biological replicates

amides, thioesters, and aryl esters, there was substantial activity toward the short-chain carboxyl esters. The carboxyl esterase activity was stable over a range of $\mathrm{pH}$ from 7.0 to 8.5 and over a wide range of temperatures $\left(30{ }^{\circ} \mathrm{C}\right.$ to $\left.80^{\circ} \mathrm{C}\right)$. The saturation kinetics were demonstrated with $p$-nitrophenyl acetate and butyrate (Table 2, Additional file 4: Figure S3).

\section{Expression of LdtP alters lipopolysaccharide structure}

Lipopolysaccharide (LPS) from E. coli BW25113, PM2405, and PM2405A strains grown with and without arabinose was extracted in parallel to isolate and analyze the lipid A characteristics [14, 15]. A triple quadrupole tandem mass spectrometric analysis of the lipid A fraction of each strain was carried out. Our analysis revealed low to no recovery of lipid A in the quintuple mutant. This result is probably a consequence of poor attachment of the LPS to the cell wall, most likely due to the absence of transpeptidases. The expression of LdtP in the E. coli quintuple mutant partially restored the lipid $A$ in the mutant strain (Fig. 7). We followed the characteristic penta-acyl di-phosphoryl species ( $\mathrm{m} / \mathrm{z}$ 1360.28) and tetra-acyl di-phosphoryl species (m/z 1569.7) as biomarkers, and they were fully restored when LdtP was expressed. Four signals (m/z 1419.12, 1450.89, 1492.80, and 1530.73), presumably penta-acyl monophosphates, were also identified. Only two of those (m/z 1492.66 and 1530.66) were observed when the mutant expressing the recombinant LdtP was analyzed. Extra assays were carried out in our laboratory to fully identify the biological role of the enzyme. However, the results obtained suggest that LdtP could be involved in the modification of the LPS, likely by eliminating acyl chains with its esterase activity. The importance of the LPS structure and composition is likely a critical factor allowing the bacteria to evade plant defenses; LdtP's putative role in altering the LPS structure identifies it as an important candidate that plays a vital role in $L$. asiaticus envelope modification and preservation in the citrus host.

\section{Discussion}

L. asiaticus encounters persistent changes in osmotic pressure within the phloem of the citrus host. The soluble solid content in the phloem fluctuates among citrus species, but it may also change within a given plant depending on the season, time of day, and the specific 


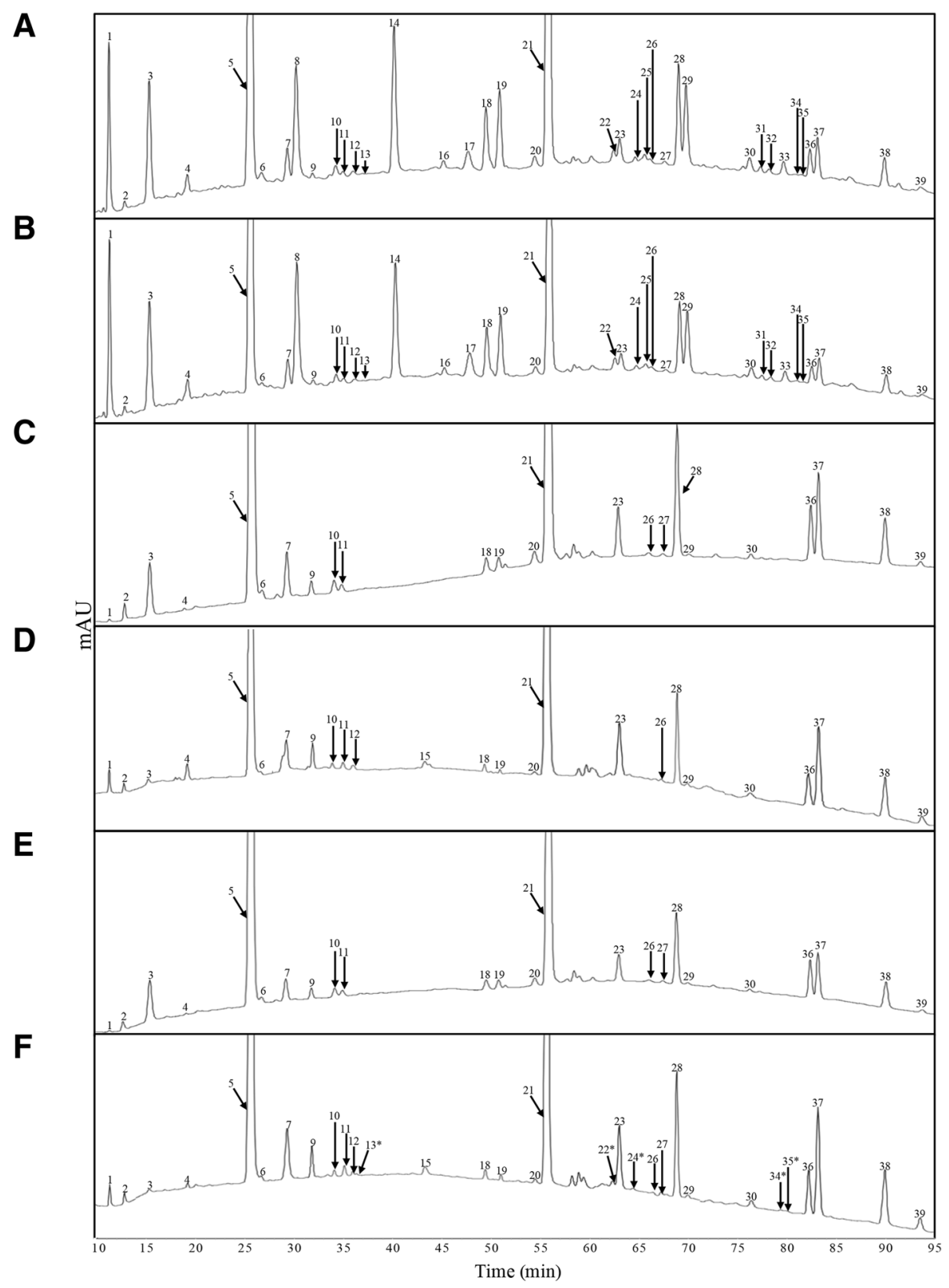

Fig. 6 Analysis of peptidoglycan profiles. HPLC chromatograms of muropeptides acquired by digestion of peptidoglycan by mutanolysin. Peaks are numbered in accordance with Table S1. Peaks that were reintroduced in the complemented strain are indicated by asterisks. a E. coli BW25113, 0\% arabinose; b E. coli BW25113, 0.02\% arabinose; c PM2405, 0\% arabinose; d PM2405, 0.02\% arabinose; e PM2405A, 0\% arabinose; f PM2405A, $0.02 \%$ arabinose

Table 2 Kinetic analysis of LdtP carboxyl esterase activity

\begin{tabular}{llllll}
\hline & $K_{0.5}{ }^{a}(\mathrm{mM})$ & $V_{\max }{ }^{a}\left(\mu\right.$ moles $\left.\mathrm{min}^{-1} \mathrm{mg}^{-1}\right)$ & Hill coefficient $\left(\mathrm{n}^{\mathrm{a}}\right)$ & $k_{\text {cat-App }}\left(\mathrm{s}^{-1}\right)$ & $k_{\text {cat-App }} / K_{0.5}\left(\mathrm{M}^{-1} \mathrm{~s}^{-1}\right)$ \\
\hline pNP-acetate & $0.44 \pm 0.035$ & $0.67 \pm 0.028$ & $2.09 \pm 0.363$ & 0.54 & $1.24 \times 10^{3}$ \\
pNP-butyrate & $0.44 \pm 0.032$ & $0.16 \pm 0.004$ & $3.12 \pm 0.662$ & 0.13 & $2.88 \times 10^{2}$ \\
\hline
\end{tabular}




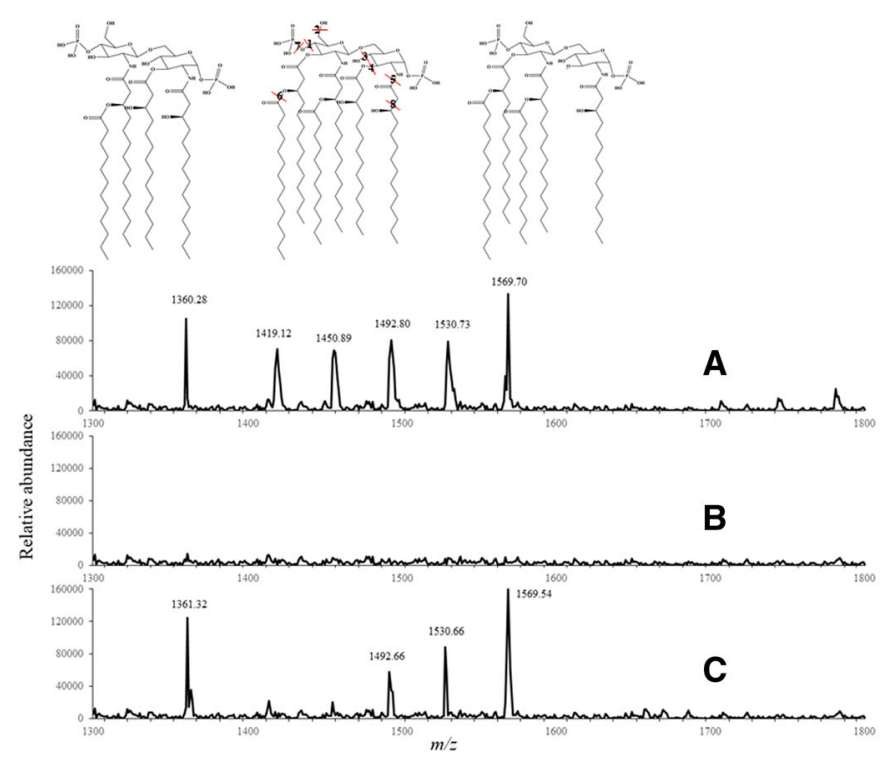

Fig. 7 Analysis of lipid A. Mass spectrometry analysis of the lipid A fraction. a E. coli BW25113, b PM2405, and c PM2405A

plant tissue [5]. The phloem of the citrus tree contains sugars, amino acids, vitamins, and inorganic ions at very high concentrations [16]. Although only about 55\% of the chemical composition of phloem sap is comprised of sugars, with sucrose accounting for $64 \%$ of all sugars, sucrose concentrations in phloem may vary from $15 \mathrm{mM}$ up to $880 \mathrm{mM}$ [16]. Thus, pathogens that reside within the phloem must have a mechanism to respond to variations in osmotic pressure. The LdtR operon from $L$. asiaticus, which includes $l d t P$, was previously characterized and identified to be involved in the osmotic stress response [5]. In agreement with this, we found that $l d t P$ was strongly induced in $L$. crescens in the presence of culture media containing a high level of osmolytes, either $\mathrm{NaCl}$ or sucrose.

In this study, we have identified and characterized LdtP, an LD-TPase displaying esterase moonlighting activity from $L$. asiaticus. The $l d t P$ gene encodes a protein with a peptidoglycan-binding domain and two YkuD LD-TPase catalytic domains that aligns with LD-TPases and amidases from other bacterial species. A structural alignment revealed the catalytic triad of LdtP and further supported the hypothesis that LdtP functions as an LD-TPase.

Due to the inability to maintain $L$. asiaticus in culture and the lack of readily available genome editing tools for $L$. crescens, the phenotypic consequences of the effects of $l d t P$ expression were studied in $E$. coli. Although there is only one gene encoding an LD-TPase in L. asiaticus, E. coli has five homologs in its genome: YcfS, YnhG, YcbB, ErfK, and YbiS [7]. A strain of E. coli lacking all five of these LD-TPases was utilized to assess the biological effects of LdtP overproduction. Expression of LdtP in the LD-TPase mutant strain restored 5 out of the 15 missing muropeptide species represented on the HPLC chromatogram. These results suggest that $L$. asiaticus modifies its peptidoglycan structure via the action of LdtP changing the relative abundance of crosslinks, presumably 3-3 cross linking inferred from LdtP structural homology, when exposed to high osmotic stress conditions. In vitro activity assays should be performed to confirm this observation.

In bacteria, these enzymes play a pivotal role in resistance to extreme conditions. Multidrug resistance in $M$. tuberculosis is mediated by L,D- transpeptidases, carbapenems being their only inhibitor. Effective treatments against tuberculosis require simultaneous inhibition of penicillin binding proteins and L,D transpeptidases $[17,18]$. L,D-transpeptidases are also used as a survival strategy by Bdellovibrio bacteriovorus, allowing the bacteria to resist cell wall degradation while the bacteria attacks its prey. B. bacteriovorus synthesizes a thicker cell wall, a phenomenon called "baiting", which depends on the availability of substrate precursors [19-21]. A similar strategy involving identical enzymatic activity is used by Clostridium difficile. In this case, the terminal D-ala is replaced by D-lactate. Remarkably, this substitution decreases the affinity of glycopeptide antibiotics several fold [20-22]. The role of cell wall $3-3$ crosslinked peptides is documented, but the fundamental contribution of these enzymes in bacterial pathosystems has only recently been discovered. Our previous results studying LdtR, the transcription factor that regulates $l d t P$ expression, supported a similar role for this protein in L. asiaticus resistance [5].

Previous analyses performed in A. tumefaciens and $S$. meliloti indicated the presence of a highly cross-linked peptidoglycan (64\%) [23]. Since only prokaryotes 
produce peptidoglycans, its detection by pattern recognition receptors is widespread in eukaryotic hosts (i.e., Toll-like receptor 2 and NOD receptors in mammals; peptidoglycan recognition proteins PGRPs in Drosophila) [24]. In plants, peptidoglycan from both gram-positive and gram-negative bacteria elicits defense responses in Arabidopsis [25-27]. Recently, LYM1 and LYM3 have been identified as peptidoglycan receptors in Arabidopsis and Oryza sativa (rice) $[28,29]$. Notably, those genes were not among the highly expressed genes in citrus trees infected with $L$. asiaticus. We hypothesize that LdtP could be involved in modifications of the peptidoglycan structure as a means of "hiding" the bacterium from the host immune system. Such modifications will favor $L$. asiaticus persistence within the host while the bacteria evade detection and elimination by the plant immune system.

Analysis of the lipid A moiety of the LPS in the various $E$. coli strains investigated showed alterations in structure. The E. coli quintuple mutant LD-TPase strain expressing LdtP showed a different pattern of lipid A composition compared to the wild type. This result, along with the demonstrated esterase activity in vitro, supports an additional role for LdtP in the modification of the cell LPS. LPS is extremely heterogeneous; for example, in Rhizobium species, the specific modifications in structure can vary in response to external stimuli, such as environmental conditions [30]. LPS is essential in symbiotic bacteria and is a strong immune response activator in pathogenic bacteria [31, 32]. Modifications of the LPS structure, specifically in the lipid A region, have been shown to have dramatic effects on bacterial survival and virulence and can alter host immune responses [33]. Modifications of $L$. asiaticus lipid A by LdtP, probably due esterase activity, may also contribute to the survival strategy of this bacterium, allowing it to thrive in the phloem of the citrus host.

The moonlighting activity proposed for LdtP, based on the esterase activity and modification of LPS, is the first report associating such activity with a cell wall crosslinking enzyme. This dual job is likely a consequence of a drastic evolutionary reduction of the genetic information encoded in $L$. asiaticus' genome. The intracellular lifestyle of this bacteria and genomic reduction has allowed for fewer encoded enzymes required to fulfill all basic cellular needs.

Transcriptional activation of $l d t P$ was crucial to increase osmotic stress tolerance in a phylogenetically-related surrogate species, S. meliloti, during assay conditions [5]. This suggests that the activity of LdtP may be essential to the survival of $L$. asiaticus in response to the high osmotic pressure sustained within the citrus phloem by increasing the rigidity of the cell wall through an increase in the abundance of 3-3 cross-links. Alternatively, L. asiaticus may also mask the peptidoglycan and LPS from detection by the citrus plant immune system by modification that improves viability and survival within the host.

\section{Conclusions}

These data confirm that LdtP is involved in the osmotic stress response and indicate LdtP's likely role in $L$. asiaticus cell wall rearrangement that may promote the persistence of this bacterium in the phloem of citrus plants. Targeting LdtP for the development of therapeutic agents against HLB is an approach that will have a significant effect on survival of this pathogen in the host.

\section{Materials and methods \\ Chemicals}

All restriction enzymes, RNase $\mathrm{H}\left(5000 \mathrm{U} \mathrm{mL}^{-1}\right)$, and DNase I $\left(2000 \mathrm{U} \mathrm{mL}^{-1}\right)$ were purchased from New England Biolabs, Inc.. Halt ${ }^{\mathrm{mm}}$ protease \& phosphatase inhibitor cocktail, EDTA-free (100X) was purchased from Thermo Scientific. Brain heart infusion was purchased from Difco Laboratories. L-(+)-arabinose, $\alpha$-amylase from Aspergillus oryzae $\left(30 \mathrm{U} \mathrm{mg}^{-1}\right)$, protease from Streptomyces griseus (Pronase $\mathrm{E} ; \geq 3.5 \mathrm{U} \mathrm{mg}^{-1}$ ), mutanolysin from Streptomyces globisporus ATCC 21553 ( $\geq 4000 \mathrm{U}$ $\left.\mathrm{mg}^{-1}\right)$, sodium azide, all antibiotics, and culture media components were purchased from Sigma-Aldrich. All other chemicals were of analytical grade.

\section{Bacterial strains and growth conditions}

Bacterial strains and plasmids are listed in Table 3. Escherichia coli strains were grown in Luria-Bertani (LB) broth, LB agar, Terrific (TB) broth, and M9 minimal medium at $37^{\circ} \mathrm{C}$, as indicated. When required, the media was supplemented with ampicillin $\left(100 \mu \mathrm{g} \mathrm{mL}^{-1}\right)$ and kanamycin $\left(50 \mu \mathrm{g} \mathrm{mL}^{-1}\right)$. Gene expression was induced with arabinose, as indicated.

L. crescens BT- 1 was cultured at $25^{\circ} \mathrm{C}$ with moderate agitation (200 rpm) in modified BM7 media, pH 6.9, as described previously [5, 34]. This culture media was composed of 1\% Brain Heart Infusion, 15\% Fetal Bovine Serum, 30\% TMN-FH insect medium, $\alpha$-Ketoglutaric acid $\left(2 \mathrm{mg} \mathrm{mL}^{-1}\right)$, ACES $\left(10 \mathrm{mg} \mathrm{mL}^{-1}\right)$, and potassium hydroxide $\left(3.75 \mathrm{mg} \mathrm{mL}^{-1}\right)$.

\section{DNA manipulations}

Primers are listed in Table 4. Standard methods were used for cloning, ligation, and transformation [35]. PCR products were purified using Qiaquick purification kits (Qiagen), and plasmids were isolated using QIAprep Spin Miniprep Kit (Qiagen).

For protein expression and purification, the $l d t P$ gene was amplified from $L$. asiaticus str. psy62 chromosomal DNA by PCR and then cloned into the p15TV-L plasmid (GenBank accession EF456736; Structural Genomics Consortium, Toronto) as described previously [36]. 
Table 3 Bacterial strains and plasmids used in this study

\begin{tabular}{|c|c|c|}
\hline Name & Relevant genotype & Reference \\
\hline \multicolumn{3}{|l|}{ Bacterial Strain } \\
\hline L. crescens BT-1 & Standard strain & Leonard et al. (2012) [34] \\
\hline E. coli DH5a & 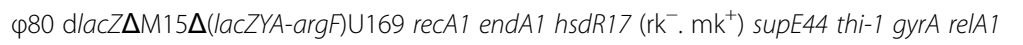 & Laboratory stock \\
\hline E. coli BL21 (DE3) & F- ompT gal dcm lon hsdSB(rB- mB-) $\lambda(D E 3$ [lacl lacUV5-T7 gene 1 ind1 sam7 nin5]) & Life Technologies \\
\hline E. coli BW25113 & $\Delta\left(\right.$ araD-araB)567 $\Delta / a c Z 4787\left(:\right.$ rrnB-3) $\lambda^{-}$rph-1 $\Delta($ rhaD-rhaB) 568 hsdR514; (WT) & Kitagawa et al. (2005) [48] \\
\hline$J C 1001$ & E. coli BW25113 pJFC1; $\left(\Delta / d t 5 / l d t P^{+}\right)$ & This study \\
\hline PM2405 & E. coli BW25113 $\Delta y n h G 753:$ :frt $\Delta y b i S 790:$ :frt $\Delta y c f 5775:$ :frt $\Delta$ erfK761::frt $\Delta y c b B 742:: k a n ;(\Delta / d t 5)$ & Sanders \& Pavelka (2013) [7] \\
\hline PM2405A & E. coli PM2405 pJFC1; $\left(\Delta / d t 5 / / d t P^{+}\right)$ & This study \\
\hline PM2405A1 & E. coli PM2405 pJFC1F; $\left(\Delta / d t 5 / / d t P^{+}-F L A G\right)$ & This study \\
\hline \multicolumn{3}{|l|}{ Plasmid } \\
\hline P15TV-L & Expression vector for purification of proteins by nickel affinity chromatography. $A p^{R}$ & $\begin{array}{l}\text { Structural Genomics Consortium, } \\
\text { University of Toronto }\end{array}$ \\
\hline pBAD24 & $\begin{array}{l}\text { Arabinose-inducible araBAD expression vector; optimized Shine-Dalgarno } \\
\text { box (RBS), no purification tag in MCS; Ap }\end{array}$ & Guzman et al. (1995) [12] \\
\hline pJFC1 & pBAD24 derivative containing IdtP from L. asiaticus (Ncol/Accl); $A p^{R}$ & This study \\
\hline $\mathrm{pJFC1F}$ & $\begin{array}{l}\text { pBAD24 derivative containing IdtP from L. asiaticus with a C-terminal FLAG-tag } \\
\text { (Ncol/Accl); } \mathrm{Ap}^{\mathrm{R}}\end{array}$ & This study \\
\hline
\end{tabular}

Cloning in the pBAD24 plasmid was performed by amplifying $l d t P$ from $L$. asiaticus str. psy 62 chromosomal DNA by PCR, using the primers in Table 4. The PCR product was verified by agarose gel electrophoresis, and both the PCR product and the pBAD24 plasmid were digested with NcoI and AccI in a simultaneous double digestion reaction according to the manufacturer's instructions. A ligation reaction was performed with the Quick Ligation ${ }^{\text {Tx }}$ Kit (New England Biolabs, Inc.). Insertion of a FLAG-tag sequence at the

Table 4 Primers used in this study

\begin{tabular}{|c|c|}
\hline Primer & Oligonucleotide Sequence $\left(5^{\prime} \rightarrow 3^{\prime}\right)$ \\
\hline \multicolumn{2}{|l|}{ Protein Purification } \\
\hline LdtP_Ext_Fw & GGGGTGATCAGATTGCGTAT \\
\hline LdtP_Ext_Rv & ATCCTTGCGCCTCTAAAACA \\
\hline LdtP_LIC_FW & TTGTATTTCCAGGGCGTAGAGAAACCCATTCATGC \\
\hline LdtP_LIC_Rv & CAAGCTTCGTCATCAGTCAGAATCTATAGGATGATCCT \\
\hline \multicolumn{2}{|l|}{ pBAD24 Cloning } \\
\hline LdtP_Ncol_Fw & CGATTAGCCATGGTTGGATATTTAAAGATAAATAAG \\
\hline LdtP_Accl_Rv & TTAATTAGTCGACGATCAGTCAGAATCTATAG \\
\hline pBAD24-LdtP_C-terminalFLAG_Fw & gatgatgataaaTGATCGTCGACCTGCAGG \\
\hline pBAD24-LdtP_C-terminalFLAG_Rv & atctttataatcGTCAGAATCTATAGGATGATCCTC \\
\hline \multicolumn{2}{|l|}{ Sequencing } \\
\hline T7-Promoter & TAATACGACTCACTATAGGG \\
\hline T7-Terminator & GCTAGTTATTGCTCAGCGG \\
\hline pBAD-Forward & ATGCCATAGCATTTTATCC \\
\hline pBAD-Reverse & GATTTAATCTGTATCAGG \\
\hline \multicolumn{2}{|l|}{ qRT-PCR } \\
\hline B488_16S_FW & CAGAACCTTACCAGCCCTTG \\
\hline B488_16S_Rv & ATTAGCTCCGCCTCACGACT \\
\hline B488_10900_Fw & GGTGGCCACAGGTGGTAATA \\
\hline B488_10900_Rv & TAACCCATGTCGTGCTTGAA \\
\hline
\end{tabular}


C-terminus of the ldtP gene in the pBAD24 vector was completed by PCR with the primers listed in Table 4 and the $\mathrm{Q}^{\circ}$ Site-Directed Mutagenesis Kit (New England Biolabs, Inc.). Clones were confirmed by sequencing using $\mathrm{pBAD}$ universal primers.

\section{Protein purification}

The overexpression of a soluble His-tagged LdtP fusion protein (residues 27-431) in E. coli BL21-Star(DE3) cells (Life Technologies) was performed exactly as described previously $[4,5]$.

Protein purification was also performed as described previously by Pagliai et al. [4] but with minor adjustments to the purification buffers. The binding buffer, wash buffer, and elution buffer were all composed of $500 \mathrm{mM} \mathrm{NaCl}$, $5 \%$ glycerol, $50 \mathrm{mM}$ Hepes $\mathrm{pH} 7.5$, and $0.5 \mathrm{mM}$ TCEP; however, the imidazole concentration differed in each at 5 $\mathrm{mM}, 0.5 \mathrm{mM}$, and $250 \mathrm{mM}$, respectively. The purified protein was dialyzed against $250 \mathrm{mM} \mathrm{NaCl}, 5 \%$ glycerol, 10 $\mathrm{mM}$ Hepes $\mathrm{pH} 7.5,0.5 \mathrm{mM}$ TCEP at $4{ }^{\circ} \mathrm{C}$ overnight. The final protein concentration was determined using the Bio-Rad protein assay (Bio-Rad), before the purified protein was aliquoted and stored at $-80^{\circ} \mathrm{C}$.

\section{Size-exclusion chromatography}

Size exclusion chromatography with a Superose 12,100/ 300 GL gel filtration column (GE Healthcare) was completed as described by Pagliai et al. [4].

\section{Cell fractionation}

Cells were fractionated into cytoplasmic, periplasmic, and membrane fractions as described previously, with some modifications $[37,38]$. Briefly, cells were grown in $100 \mathrm{~mL}$ cultures to an $\mathrm{OD}_{600}=1.0$, collected by centrifugation, and gently resuspended in $1 \mathrm{~mL}$ of TSE buffer (200 mM Tris- $\mathrm{HCl}$ pH 8.0, $500 \mathrm{mM}$ sucrose, $1 \mathrm{mM}$ EDTA, 1X protease \& phosphatase inhibitor), pre-chilled to $4{ }^{\circ} \mathrm{C}$ [38]. The cell suspension was incubated on ice for $30 \mathrm{~min}$ to allow for the complete release of periplasmic proteins. Centrifugation at $16,000 \times g$ for $30 \mathrm{~min}$ at 4 ${ }^{\circ} \mathrm{C}$ separated the periplasmic fraction (supernatant) from the spheroplasts, which contain the cytoplasmic and membrane fractions. The pelleted spheroplasts were resuspended in $750 \mu \mathrm{L}$ of sonication buffer $(50 \mathrm{mM}$ Tris- $\mathrm{HCl} \mathrm{pH} 7.5,50 \mathrm{U}$ RNase $\mathrm{H}, 40 \mathrm{U}$ DNase I, $2.5 \mathrm{mM}$ $\mathrm{MgCl}_{2}, 0.5 \mathrm{mM} \mathrm{CaCl}_{2}, 75 \mathrm{mM} \mathrm{KCl}$ ), incubated for $5 \mathrm{~min}$ on ice, and lysed by sonication. Cellular debris was removed by centrifugation $\left(3000 \times g, 15 \mathrm{~min}, 4{ }^{\circ} \mathrm{C}\right)$. The supernatant, containing the cytoplasmic and membrane fractions, was ultracentrifuged at $300,000 \times g$ for $2 \mathrm{~h}$ at $4{ }^{\circ} \mathrm{C}$ to further separate the fractions. The supernatant contained the cytoplasmic fraction, and the pellet, containing the membrane fraction, was resuspended in membrane protein extraction buffer (50 mM Tris- $\mathrm{HCl} \mathrm{pH} 8.0,2 \%$
Triton X-100, $10 \mathrm{mM} \mathrm{MgCl} 2$ ). All fractions were aliquoted and stored at $-80^{\circ} \mathrm{C}$.

\section{Western blot}

SDS-PAGE of cell fractions was performed according to the method described by Laemmli (1970) [39]. Cell fraction samples were prepared by incubation at $100^{\circ} \mathrm{C}$ for $5 \mathrm{~min}$ and separated on $12.5 \%$ polyacrylamide gels. Proteins were transferred to Amersham Hybond ${ }^{\mathrm{m} w}-\mathrm{N}^{+}$ nylon hybridization transfer membranes (GE Healthcare) at $450 \mathrm{~mA}$ for $40 \mathrm{~min}$ in a semi-dry transfer and then probed with mouse polyclonal anti-FLAG antibody (Sigma-Aldrich). The membranes were then incubated with rabbit anti-mouse antibody coupled to horseradish peroxidase. The presence of LdtP was detected by chemiluminescence using the Amersham ECL ${ }^{\text {max }}$ western blotting detection reagents (GE Healthcare) according to the manufacturer's instructions.

\section{qRT-PCR}

L. crescens BT-1 cells were cultured at $200 \mathrm{rpm}$ in BM7 culture media amended with $\mathrm{NaCl}(50 \mathrm{mM}, 100 \mathrm{mM})$ or sucrose $(75 \mathrm{mM}, 100 \mathrm{mM}, 150 \mathrm{mM})$ at $25^{\circ} \mathrm{C}$. The cells were collected by centrifugation at $4{ }^{\circ} \mathrm{C}$ when the cultures reached mid-exponential phase $\left(\mathrm{OD}_{600}=0.3\right)$. Total RNA was extracted with the RiboPure-Bacteria kit (Life Technologies), and cDNA was synthesized using the iScript cDNA synthesis kit (Bio-Rad).

qRT-PCR assays were carried out in a Bio-Rad iCycler IQ apparatus, using the iQ SYBR Green SuperMix (Bio-Rad). The changes of expression $\left(C_{t}\right.$ values) between the samples treated with $\mathrm{NaCl}$ or sucrose compared to the control were determined using the $2^{-\Delta \Delta C t}$ method. The sequence of primers for B488_10900 and 16S rRNA, used as an internal control, are listed in Table 4.

\section{Growth curve assay and generation time calculation}

E. coli strains were grown in LB or Terrific broth supplemented with increasing concentrations of arabinose $(0-0.2 \%)$. The optical density $(600 \mathrm{~nm})$ of the cultures was recorded hourly, and a plot containing the $\log \left(\mathrm{OD}_{600}\right)$ versus time was created with Origin 9.0 software (OriginLab) to facilitate the calculation of the growth rate constant $(k)$ and the generation time $(g=1 / k)$ as previously described [4]. The assays were performed in triplicates, and statistical significance was determined using a Student's t-test.

\section{Purification and digestion of the peptidoglycan sacculus}

E. coli strains were grown in $250 \mathrm{~mL}$ of $\mathrm{M} 9$ broth at $37^{\circ} \mathrm{C}$ to late exponential phase, approximately to $\mathrm{OD}_{600}=0.6$. Peptidoglycan was purified as described previously with a few modifications [40-42]. The cultures were rapidly chilled in an ice/ethanol bath before the cells were 
collected by centrifugation at $12,000 \times g$ for $15 \mathrm{~min}$ at $4{ }^{\circ} \mathrm{C}$. The cells were washed once with $20 \mathrm{mM}$ sodium acetate buffer, pH 5.0, pre-chilled to $4{ }^{\circ} \mathrm{C}$, and resuspended in 5 $\mathrm{mL}$ of the same buffer [41]. The cell suspension was added dropwise to $5 \mathrm{~mL}$ of boiling $10 \% \operatorname{SDS}\left(100^{\circ} \mathrm{C}\right)$ and incubated at this temperature with continual stirring for $3 \mathrm{~h}$. After this incubation, the heat was turned off, and the cells continued to stir overnight at room temperature. Insoluble peptidoglycan sacculi were collected by ultracentrifugation at $400,000 \times g$ for $15 \mathrm{~min}$ at room temperature, washed three times with ultrapure water, and resuspended in $800 \mu \mathrm{L}$ of Buffer A $(10 \mathrm{mM}$ Tris- $\mathrm{HCl}, \mathrm{pH} 7.2+0.06 \%$ $(w / v) \mathrm{NaCl})[40]$.

To eliminate high-molecular weight glycogen, the sacculi were treated with $200 \mu \mathrm{L}$ of $1 \mathrm{mg} \mathrm{mL}^{-1} \alpha$-amylase in Buffer A $\left(200 \mu \mathrm{g} \mathrm{mL}^{-1}\right.$ final concentration) and incubated at $37^{\circ} \mathrm{C}$ for $1 \mathrm{~h}$. To remove covalently-bound lipoprotein, the sacculi were treated with $200 \mu \mathrm{L}$ of $1 \mathrm{mg}$ $\mathrm{mL}^{-1}$ pre-activated Pronase E in Buffer A $\left(200 \mu \mathrm{g} \mathrm{mL}^{-1}\right.$ final concentration) and incubated at $60^{\circ} \mathrm{C}$ for $2 \mathrm{~h}$. Digestions were stopped by the addition of $200 \mu \mathrm{L}$ of $6 \%$ SDS followed by boiling at $100{ }^{\circ} \mathrm{C}$ for $5 \mathrm{~min}$. Sacculi were collected by ultracentrifugation at $400,000 \times g$ for $15 \mathrm{~min}$ at room temperature, washed three times with ultrapure water to remove residual SDS, and resuspended in $200 \mu \mathrm{L}$ of $50 \mathrm{mM}$ sodium phosphate buffer, $\mathrm{pH} 6.2$.

Sacculi were digested to muropeptides by treating the samples with mutanolysin from Streptomyces globisporus ATCC 21553 at a final concentration of $40 \mu \mathrm{g}$ $\mathrm{mL}^{-1}$ at $37^{\circ} \mathrm{C}$ overnight. The samples were boiled at $100^{\circ} \mathrm{C}$ for $5 \mathrm{~min}$ to stop the digestion, and soluble muropeptides were recovered from the supernatant after centrifugation at $16,000 \times g$ for $10 \mathrm{~min}$ at room temperature. Before analysis via HPLC, muropeptides were reduced for $30 \mathrm{~min}$ at room temperature by adding an equal volume of $500 \mathrm{mM}$ borate buffer, $\mathrm{pH}$ 9.0, and sodium borohydride to a final concentration of $10 \mathrm{mg} \mathrm{mL}^{-1}$. The final $\mathrm{pH}$ of the samples was adjusted to between 3.0-4.0 with phosphoric acid. Samples were aliquoted and stored at $-80^{\circ} \mathrm{C}$.

\section{High-performance liquid chromatography (HPLC) and mass spectrometry}

Reverse-phase HPLC was used to quantify the relative abundance of individual muropeptide species in order to facilitate meaningful comparisons between bacterial strains. A Hitachi LaChrom Elite HPLC system consisting of two L-2130 pumps, an L-2200 autosampler, an L-2300 column oven, and an L-2400 UV detector was used (Hitachi). Samples were passed through a $0.22 \mu \mathrm{m}$ filter, and injection volumes of $30 \mu \mathrm{L}$ were separated by HPLC on a Hypersil ODS column $(250 \times 4.6 \mathrm{~mm}, 3 \mu \mathrm{m}$; Thermo Scientific) using a linear gradient from $50 \mathrm{mM}$ sodium phosphate, $\mathrm{pH} 4.31$, containing $1 \mu \mathrm{g} \mathrm{mL}^{-1}$ sodium azide to $75 \mathrm{mM}$ sodium phosphate, $\mathrm{pH} 4.95$, containing $15 \%$ methanol over $135 \mathrm{~min}$ at $55^{\circ} \mathrm{C}$ with a flow rate of $0.5 \mathrm{~mL} \mathrm{~min}^{-1}$ [42]. UV detection was performed at $205 \mathrm{~nm}$. Data were analyzed with EZChrom Elite 3.3.2 software (Agilent). The abundance of each muropeptide was determined as the peak area percentage of the total integrated peak area [6, 43]. Mass spectrometry: a TSQ Quantum Access MAX Triple Quadrupole tandem mass spectrometric analysis system (Thermo Scientific, San Jose, CA, USA) was carried out using a heated-electrospray ionization in negative mode (HESI-) in this study. The ion spray voltage, capillary temperature, and collision energy were set at $3500 \mathrm{kV}, 300^{\circ} \mathrm{C}$, and -10 $\mathrm{eV}$, respectively. The samples $\left(10 \mu \mathrm{g} \mathrm{mL}^{-1}\right.$ in $50 \%$ ethanol $)$ were injected into the instrument by a syringe pump, and the flow rate of the syringe pump was set to $10 \mu \mathrm{L} \mathrm{min}^{-1}$.

\section{Esterase and amidase activity assay}

Carboxyl esterase, aryl esterase, and thioesterase activities were assessed using $p$-nitrophenyl esters, naphthyl esters, and acyl-CoA substrates, respectively, and activity was measured spectrophotometrically by continuous reading at 400 $\mathrm{nm}\left(\varepsilon=10,500 \mathrm{M}^{-1} \mathrm{~cm}^{-1}\right), 310 \mathrm{~nm} \quad\left(\varepsilon=3000 \mathrm{M}^{-1} \mathrm{~cm}^{-1}\right)$, or $412 \mathrm{~nm}\left(\varepsilon=13,600 \mathrm{M}^{-1} \mathrm{~cm}^{-1}\right)$. The activity assays were carried out as described previously [44-46]. All assays were conducted at $30^{\circ} \mathrm{C}$, and the reactions were started by adding purified $\mathrm{His}_{6 \mathrm{X}}$-LdtP at a final concentration of $20 \mu \mathrm{g}$ $\mathrm{mL}^{-1}$. Control reactions, with the addition of buffer in the place of enzyme, were used to estimate any auto-hydrolysis of the substrate. The kinetic parameters were determined by plotting the initial velocities over increasing initial substrate concentrations and generating curves fitted with the Hill equation using MicroCal Origin 9.0 (OriginLab).

Amidase activity was measured via an Ammonia Assay Kit (Sigma-Aldrich), as the release of ammonia follows hydrolysis of an amide bond. Amides with various acyl chain lengths were tested as substrates. The reactions were carried out at $30^{\circ} \mathrm{C}$, and the reactions were started by adding purified $\mathrm{His}_{6 \mathrm{X}} \mathrm{-LdtP}$ at a final concentration of $20 \mu \mathrm{g} \mathrm{mL}^{-1}$. Control reactions, with the addition of buffer in the place of enzyme, were used to estimate any auto-hydrolysis of the substrate. The concentration of resulting ammonia was measured according to the manufacturer's protocol.

\section{LPS extraction and lipid a isolation}

E. coli strains were grown in $250 \mathrm{~mL}$ of LB broth with or without $0.02 \%$ arabinose at $37^{\circ} \mathrm{C}$ to late exponential phase, approximately to $\mathrm{OD}_{600}=0.6$, and lyophilized. LPS was extracted as described previously with a few modifications [14]. Lyophilized cells were weighed out to $120 \mathrm{mg}$ each, resuspended in $5 \mathrm{~mL}$ of TRI Reagent (Sigma-Aldrich), and incubated at room temperature for $15 \mathrm{~min}$ to lyse the cells. Following incubation, $2.4 \mathrm{~mL}$ of chloroform was added, and the samples were vigorously 
vortexed and incubated at room temperature for $10 \mathrm{~min}$ to facilitate a phase separation. The samples were centrifuged at $12,000 \times g$ for $10 \mathrm{~min}$ to separate the phases, and the aqueous phase was transferred to a new tube. Three water extraction steps were completed to ensure complete removal of LPS from the organic phase; the aqueous phases from each step were pooled and lyophilized.

Lipid A was isolated from whole LPS via mild acid hydrolysis as described by Yi and Hackett [14]. Briefly, lyophilized LPS samples were resuspended in 1\% SDS in 10 $\mathrm{mM}$ sodium acetate $(\mathrm{pH} 4.5)$ and incubated in an ultrasound bath to completely dissolve the sample. The samples were then heated at $100^{\circ} \mathrm{C}$ for $1 \mathrm{~h}$, lyophilized, and washed twice with acidified ethanol to remove the SDS. Isolated lipid A was lyophilized and stored at $-80^{\circ} \mathrm{C}$.

The lipid A was visualized by Tris-Tricine SDS-PAGE followed by silver staining as described by Schägger [15].

\section{Additional files} Additional file 1: Figure S1. SDS-PAGE showing purification of
recombinant His-tagged LdtP. (TIF $347 \mathrm{~kb}$ )

Additional file 2: Figure S2. Growth curves for E. coli BW25113, PM2405, and PM2405A with various concentrations of arabinose. (TIF $269 \mathrm{~kb}$ )

Additional file 3: Table S1. Peak areas of HPLC-separated muropeptides isolated from E. coli strains. Peak areas were calculated as a percentage of the total integrated area and are numbered as labeled in Fig. 6. *Peaks that were reintroduced in the complemented strain. (XLS $33 \mathrm{~kb}$ )

Additional file 4: Figure S3. Saturation kinetics for $p$-nitrophenyl acetate and butyrate. (TIF $173 \mathrm{~kb}$ )

\section{Abbreviations}

DD-TPase: D,D-transpeptidase; LD-TPase: L,D-transpeptidase;

PG: Peptidoglycan

\section{Acknowledgements}

We would like to thank Kaylie Padgett and Evon DeBose-Scarlett for critical reading of the manuscript.

\section{Funding}

This work is supported by the Specialty Crop Research Initiative (Award number 2015-70016-23029 to GLL and CFG), and the Plant Biotic Interactions Program (Award number 2017-03060 to CFG) from the USDA National Institute of Food and Agriculture, http://nifa.usda.gov/. Any opinions, study design, findings, data interpretation, conclusions, or recommendations expressed in this publication are those of the author(s) and do not necessarily reflect the view of the U.S. Department of Agriculture.

\section{Availability of data and materials}

The datasets used and/or analyzed during the current study are available from the corresponding author on reasonable request.

\section{Authors' contributions}

JC, DZ, and CG designed, performed, and analyzed the experiments. FP advised/ planned experiments and aided in analysis and interpretation of data. JC and CG wrote the paper. CG and GL conceived and coordinated the study. All authors reviewed the results and approved the final version of the manuscript.

\section{Authors' information}

Not Applicable

Ethics approval and consent to participate

Not applicable
Consent for publication

Not applicable

\section{Competing interests}

The authors declare that they have no competing interests.

\section{Publisher's Note}

Springer Nature remains neutral with regard to jurisdictional claims in published maps and institutional affiliations.

Received: 7 June 2018 Accepted: 19 November 2018 Published online: 29 November 2018

\section{References}

1. Gottwald TR. Current epidemiological understanding of citrus huanglongbing. Annu Rev Phytopathol. 2010;48:119-39 Available from: http://www.ncbi.nlm.nih.gov/pubmed/20415578. Cited 4 June 2018.

2. Bové JM. Huanglongbing: a destructive, newly-emerging, century-old disease of citrus. J Plant Pathol. 2006;88:7-37 Available from: http://www. sipav.org/main/jpp/index.php/jpp/article/view/828. Cited 4 June 2018.

3. Duan Y, Zhou L, Hall DG, Li W, Doddapaneni H, Lin H, et al. Complete genome sequence of citrus huanglongbing bacterium, ' Candidatus liberibacter asiaticus' obtained through metagenomics. Mol Plant-Microbe Interact. 2009;22:1011-20 The American Phytopathological Society. Available from: http://apsjournals.apsnet.org/doi/10.1094/MPMl-22-8-1011. Cited 4 June 2018.

4. Pagliai FA, Gonzalez CF, Lorca GL. Identification of a ligand binding pocket in LdtR from Liberibacter asiaticus. Front Microbiol. 2015;6:1-13 Frontiers Media SA. Available from: http://www.ncbi.nlm.nih.gov/pubmed/26635775. Cited 4 June 2018.

5. Pagliai FA, Gardner CL, Bojilova L, Sarnegrim A, Tamayo C, Potts AH, et al. The transcriptional activator LdtR from "Candidatus Liberibacter asiaticus" mediates osmotic stress tolerance. PLoS Pathog. 2014;10:e1004101 Mackey D, editor. Public Library of Science. Available from: http://dx.plos.org/10. 1371/journal.ppat.1004101. Cited 4 June 2018.

6. Glauner B, Holtje J-V, Schwarz U. The composition of the murein of Escherichia coli. J Biol Chem. 1988;263:10088-95 American Society for Biochemistry and Molecular Biology. Available from: http://www.ncbi.nlm. nih.gov/pubmed/3292521. Cited 4 Jun 2018.

7. Sanders AN, Pavelka MS. Phenotypic analysis of Eschericia coli mutants lacking L,D-transpeptidases. Microbiology. 2013;159:1842-52 Available from: http://www.ncbi.nlm.nih.gov/pubmed/23832002. Cited 4 June 2018.

8. Marchler-Bauer A, Derbyshire MK, Gonzales NR, Lu S, Chitsaz F, Geer LY, et al. CDD: NCBI's conserved domain database. Nucleic Acids Res. 2015:43: D222-6 Available from: http://www.ncbi.nlm.nih.gov/pubmed/25414356. Cited 4 June 2018.

9. Käll L, Krogh A, Sonnhammer EL. A combined transmembrane topology and signal peptide prediction method. J Mol Biol. 2004;338:1027-36 Academic Press. Available from: https://www.sciencedirect.com/science/ article/pii/S0022283604002943?via\%3Dihub. Cited 4 June 2018.

10. Artimo P, Jonnalagedda M, Arnold K, Baratin D, Csardi G, de Castro E, et al. ExPASy: SIB bioinformatics resource portal. Nucleic Acids Res. 2012;40:W597603 Oxford University Press. Available from: https://academic.oup.com/nar/ article-lookup/doi/10.1093/nar/gks400. Cited 4 June 2018.

11. Kelley LA, Mezulis S, Yates CM, Wass MN, Sternberg MJE. The Phyre2 web portal for protein modeling, prediction and analysis. Nat Protoc. 2015;10: 845-58 Nature Publishing Group. Available from: http://www.nature.com/ doifinder/10.1038/nprot.2015.053. Cited 4 June 2018.

12. Guzman LM, Belin D, Carson MJ, Beckwith J. Tight regulation, modulation, and high-level expression by vectors containing the arabinose PBAD promoter. J Bacteriol. 1995;177:4121-30 Available from: http://jb.asm.org/ content/177/14/4121.full.pdf. Cited 4 June 2018.

13. Magnet S, Dubost L, Marie A, Arthur M, Gutmann L. Identification of the L,D-transpeptidases for peptidoglycan cross-linking in Escherichia coli. J Bacteriol. 2008;190:4782-5 American Society for Microbiology. Available from: http://www.ncbi.nlm.nih.gov/pubmed/18456808. Cited 4 June 2018.

14. Yi EC, Hackett M. Rapid isolation method for lipopolysaccharide and lipid A from gram-negative bacteria. Analyst. 2000;125:651-6 Royal Society of Chemistry. Available from: http://xlink.rsc.org/?DOl=b000368i. Cited 4 June 2018.

15. Schägger H. Tricine-SDS-PAGE. Nat Protoc. 2006;1:16-22 Available from: http://www.nature.com/doifinder/10.1038/nprot.2006.4. 
16. Hijaz F, Killiny N. Collection and chemical composition of phloem sap from Citrus sinensis L. Osbeck (sweet orange). PLoS One. 2014;9:1-11 Zhang Y, editor. Public Library of Science. Available from: http://dx.plos.org/10.1371/ journal.pone.0101830. Cited 4 June 2018.

17. Kumar P, Kaushik A, Lloyd EP, Li SG, Mattoo R, Ammerman NC, et al. Nonclassical transpeptidases yield insight into new antibacterials. Nat Chem Biol. 2017;13:54-61 Nature Publishing Group. Available from: https://doi.org/10. 1038/nchembio.2237.

18. Ntombela T, Fakhar Z, Ibeji CU, Govender T, Maguire GEM, Lamichhane G, et al. Molecular insight on the non-covalent interactions between carbapenems and I,d-transpeptidase 2 from Mycobacterium tuberculosis: ONIOM study. J Comput Aided Mol Des 2018:32:687-701. Springer International Publishing. Available from: doi: https://doi.org/10.1007/s10822-018-0121-2

19. Kuru E, Lambert C, Rittichier J, Till R, Ducret A, Derouaux A, et al. Fluorescent D-amino-acids reveal bi-cellular cell wall modifications important for Bdellovibrio bacteriovorus predation. Nat Microbiol. 2017;2:1648-57 Available from: http://www.nature.com/articles/s41564-017-0029-y.

20. Stegmann E, Frasch HJ, Kilian R, Pozzi R. Self-resistance mechanisms of actinomycetes producing lipid II-targeting antibiotics. Int J Med Microbiol 2015;305:190-195. Elsevier GmbH. Available from: doi: https://doi.org/10. 1016/j.jijmm.2014.12.015

21. Pozzi R, Coles M, Linke D, Kulik A, Nega M, Wohlleben W, et al. Distinct mechanisms contribute to immunity in the lantibiotic NAI-107 producer strain Microbispora ATCC PTA-5024. Environ Microbiol. 2016;18:118-32 Available from: http://doi.wiley.com/10.1111/1462-2920.12892.

22. Sütterlin L, Edoo Z, Hugonnet J-E, Mainardi J-L, Arthur M. Peptidoglycan crosslinking activity of L,D-transpeptidases from Clostridium difficile and inactivation of these ezymes by $\beta$-lactams. Antimicrob Agents Chemother. 2017;62:e0160717 Available from: http://aac.asm.org/lookup/doi/10.1128/AAC.01607-17.

23. Brown PJB, de Pedro MA, Kysela DT, Van der Henst C, Kim J, De Bolle X, et al. Polar growth in the Alphaproteobacterial order Rhizobiales. Proc Natl Acad Sci. 2012;109:1697-701 National Academy of Sciences. Available from: http://www.pnas.org/cgi/doi/10.1073/pnas.1114476109. Cited 4 June 2018.

24. Dziarski R, Gupta D. Peptidoglycan recognition in innate immunity. J Endotoxin Res. 2005;11:304-10 Available from: http://www.ncbi.nlm.nih.gov/ pubmed/16263004. Cited 4 Jun 2018.

25. Erbs G, Silipo A, Aslam S, De Castro C, Liparoti V, Flagiello A, et al. Peptidoglycan and muropeptides from pathogens Agrobacterium and Xanthomonas elicit plant innate immunity: structure and activity. Chem Biol. 2008;15:438-48 Available from: http://www.ncbi.nlm.nih.gov/pubmed/ 18482696. Cited 4 June 2018.

26. Gust AA, Biswas R, Lenz HD, Rauhut T, Ranf S, Kemmerling B, et al. Bacteriaderived peptidoglycans constitute pathogen-associated molecular patterns triggering innate immunity in Arabidopsis. J Biol Chem. 2007;282:32338-48 American Society for Biochemistry and Molecular Biology. Available from: http://www.ncbi.nlm.nih.gov/pubmed/17761682. Cited 4 June 2018.

27. Millet YA, Danna CH, Clay NK, Songnuan W, Simon MD, Werck-Reichhart D, et al. Innate immune responses activated in Arabidopsis roots by microbeassociated molecular patterns. Plant Cell. 2010;22:973-90 Available from: http://www.plantcell.org/cgi/doi/10.1105/tpc.109.069658.

28. Liu B, Li J-F, Ao Y, Qu J, Li Z, Su J, et al. Lysin motif-containing proteins LYP4 and LYP6 play dual roles in peptidoglycan and chitin perception in rice innate immunity. Plant Cell. 2012;24:3406-19 Available from: http://www. ncbi.nlm.nih.gov/pubmed/22872757. Cited 4 June 2018.

29. Willmann R, Lajunen HM, Erbs G, Newman M-A, Kolb D, Tsuda K, et al. Arabidopsis lysin-motif proteins LYM1 LYM3 CERK1 mediate bacterial peptidoglycan sensing and immunity to bacterial infection. Proc Natl Acad Sci. 2011;108:19824-9 Available from: http://www.ncbi.nlm.nih.gov/pubmed/ 22106285. Cited 4 June 2018.

30. Ridley BL, Jeyaretnam BS, Carlson RW. The type and yield of lipopolysaccharide from symbiotically deficient Rhizobium lipopolysaccharide mutants vary depending on the extraction method. Glycobiology. 2000;10:1013-23 Available from: http://www.ncbi.nlm.nih.gov/ pubmed/11030747. Cited 4 June 2018.

31. Janeway CA, Medzhitov R. Innate immune recognition. Annu Rev Immunol. 2002;20:197-216 Annual Reviews 4139 El Camino Way, P.O. Box 10139, Palo Alto, CA 94303-0139, USA. Available from: http://www.annualreviews.org/ doi/10.1146/annurev.immunol.20.083001.084359. Cited 4 June 2018.

32. Kannenberg EL, Rathbun EA, Brewin NJ. Molecular dissection of structure and function in the lipopolysaccharide of Rhizobium leguminosarum strain 3841 using monoclonal antibodies and genetic analysis. Mol Microbiol.
2006;6:2477-87 Wiley/Blackwell (10.1111). Available from: http://doi.wiley. com/10.1111/j.1365-2958.1992.tb01424.x. Cited 4 June 2018.

33. Rietschel ET, Kirikae T, Schade FU, Mamat U, Schmidt G, Loppnow H, et al. Bacterial endotoxin: molecular relationships of structure to activity and function. FASEB J. 1994;8:217-25 Available from: http://www.ncbi.nlm.nih. gov/pubmed/8119492. Cited 4 June 2018.

34. Leonard MT, Fagen JR, Davis-Richardson AG, Davis MJ, Triplett EW. Complete genome sequence of Liberibacter crescens BT-1. Stand Genomic Sci. 2012;7:271-83 BioMed Central. Available from: http://www.ncbi.nlm.nih. gov/pubmed/23408754. Cited 4 June 2018.

35. Sambrook J, Fritsch EF, Maniatis T. Molecular cloning: a laboratory manual. Cold Spring Harbor Laboratory Press; 1989. Available from: https://www. amazon.com/Molecular-Cloning-Laboratory-Manual-Three/dp/1936113422. Cited 4 June 2018.

36. Pagliai FA, Gardner CL, Pande SG, Lorca GL. LVIS553 transcriptional regulator specifically recognizes novobiocin as an effector molecule. J Biol Chem 2010;285:16921-16930. American Society for Biochemistry and Molecular Biology. Available from: http://www.ncbi.nlm.nih.gov/pubmed/20308066. Cited 4 June 2018.

37. Feilmeier BJ, Iseminger G, Schroeder D, Webber H, Phillips GJ. Green fluorescent protein functions as a reporter for protein localization in Escherichia coli. J Bacteriol. 2000;182:4068-76 American Society for Microbiology (ASM). Available from: http://www.ncbi.nlm.nih.gov/pubmed/ 10869087. Cited 4 June 2018.

38. Quan S, Hiniker A, Collet J-FF, Bardwell JCA. Isolation of bacteria envelope proteins. Methods Mol Biol. 2013;966:359-66 Humana Press, Totowa, NJ. Available from: http://link.springer.com/10.1007/978-1-62703-245-2_22. Cited 4 June 2018.

39. Laemmli UK. Cleavage of structural proteins during the assembly of the head of Bacteriophage T4. Nature. 1970;227:680-5 Nature Publishing Group. Available from: http://www.nature.com/doifinder/10.1038/227680a0. Cited 4 June 2018.

40. Desmarais SM, Cava F, de Pedro MA, Huang KC. Isolation and preparation of bacterial cell walls for compositional analysis by ultra performance liquid chromatography. J Vis Exp. 2014:e51183 Available from: http://www.jove. com/video/51183/isolation-preparation-bacterial-cell-walls-forcompositional-analysis. Cited 4 June 2018.

41. Dougherty TJ. Analysis of Neisseria gonorrhoeae peptidoglycan by reverse-phase, high-pressure liquid chromatography. J Bacteriol. 1985;163:69-74 Available from: http://www.ncbi.n/m.nih.gov/pubmed/3924898. Cited 4 June 2018.

42. Glauner B. Separation and quantification of muropeptides with highperformance liquid chromatography. Anal Biochem. 1988;172:451-64 Academic Press. Available from: https://www.sciencedirect.com/science/ article/pii/000326978890468X. Cited 4 June 2018.

43. Arbeloa A, Hugonnet J-E, Sentilhes A-C, Josseaume N, Dubost L, Monsempes C, et al. Synthesis of mosaic peptidoglycan cross-bridges by hybrid peptidoglycan assembly pathways in gram-positive bacteria. J Biol Chem. 2004;279:41546-56 Available from: http://www.ncbi.nlm.nih.gov/ pubmed/15280360. Cited 4 June 2018.

44. Bakshy K, Gummadi SN, Manoj N. Biochemical characterization of Alr1529, a novel SGNH hydrolase variant from Anabaena sp. PCC 7120. Biochim Biophys Acta. 2009;1794:324-34 Elsevier B.V. Available from: https://www.sciencedirect.com/science/article/pii/S1570963908003427. Cited 4 June 2018.

45. Van Straaten KE, Gonzalez CF, Valladares RB, Xu X, Savchenko AV, Sanders DAR. The structure of a putative $S$-formylglutathione hydrolase from Agrobacterium tumefaciens. Protein Sci. 2009;18:2196-202 Wiley-Blackwell. Available from: http://doi.wiley.com/10.1002/pro.216. Cited 4 June 2018.

46. Berge RK, Farstad M. Long-chain fatty acyl-CoA hydrolase from rat liver mitochondria. Methods Enzymol. 1981;71:234-42 Available from: http:// www.ncbi.nlm.nih.gov/pubmed/6116156. Cited 4 June 2018.

47. Robert $X$, Gouet P. Deciphering key features in protein structures with the new ENDscript server. Nucl Acids Res. 2014;42:W320-4 Available from: https://www.ncbi.nlm.nih.gov/pmc/articles/PMC4086106/.

48. Kitagawa M, Ara T, Arifuzzaman M, loka-Nakamichi T, Inamoto E, Toyonaga $\mathrm{H}$, et al. Complete set of ORF clones of Escherichia coli ASKA library (A complete set of $E$. coli K-12 ORF archive): unique resources for biological research. DNA Res. 2005;12:291-9 Oxford University Press. Available from: https://academic.oup.com/dnaresearch/article-lookup/doi/10.1093/dnares/ dsi012. Cited 4 June 2018. 